\title{
Introduction: Illicit Firearms Market in Europe and Beyond
}

\author{
Jana Arsovska
}

Published online: 2 August 2014

(C) Springer Science+Business Media Dordrecht 2014

The illegal arms trade is a problem that impacts every country in the world, and civilian populations bear the brunt of human rights violations associated with this trade. The United Nations (UN) Office for Disarmament Affairs (2013) explains the problem as "a worldwide scourge." Similarly, security reports published by the European Union (EU) frequently note that illicit arms trafficking presents a serious threat to security within and outside the EU. This special issue of the European Journal on Criminal Policy and Research brings together contributions from academics and practitioners from different parts of the world in an effort to study the illicit firearms market in Europe and beyond. It examines the political, criminal and cultural demand for weapons across socio-cultural space as well as the roles that states, violent non-state actors and civilians play in this market. It aims to explain the need for, and supply of, illicit firearms in Europe, Africa, Latin America, North America, and Asia. The articles contribute toward the scarce literature on the topic of illicit firearms, and provide policy recommendations for criminal justice practitioners, governments and non-governmental organizations alike.

\section{Definitions and Trends}

Firearm trafficking as defined in the UN Protocol against the Illicit Manufacturing of and Trafficking in Firearms, Their Parts and Components and Ammunition, refers to the unauthorized “...import, export, acquisition, sale, delivery, movement or transfer of firearms, their parts and components and ammunition..." across internal or state borders (UNGA 2001: 4). The term trafficking is also used to designate the intentional diversion of firearms from legal to illegal commerce, without involving the movement of items across physical borders. Illicit manufacture is closely tied to the act of firearm trafficking and it incorporates the "manufacture or assembly of firearms, firearm parts and components or ammunition" from illicitly produced parts (UNGA 2001: 3).

There are at least 875 million combined civilian, law enforcement and military firearms in the world (Small Arms Survey 2012). The value of the documented global authorized trade in firearms has been estimated at approximately US\$1.58 billion in 2006, with unrecorded but

\footnotetext{
J. Arsovska $(\bowtie)$

John Jay College of Criminal Justice, 524 W 59th St. North Hall Room\# 3257s, New York, NY 10019, USA

e-mail: jarsovska@jjay.cuny.edu
} 
licit transactions making up another US\$100 million. The most commonly cited estimate for the size of the illicit market is 10-20 percent of the licit market, which would be about US\$170 million to US\$320 million per annum (Small Arms Survey 2012). While there are various types of arms that are trafficked, small arms and light weapons (SALW) ${ }^{1}$ trafficking has been instrumental in many of the world's conflicts since 1990, with 90 percent of all war casualties since World War II being attributed to small arms weaponry (Bassiouni 2010; Stohl 1999; Shah 2006).

The majority of SALW producers are located in the West. According to the Small Arms Survey, in 2010, the top exporters of SALW (those with annual exports of at least USD 100 million), according to available customs data, were (in descending order) the United States, Germany, Italy, Brazil, Switzerland, Israel, Austria, the Russian Federation, South Korea, and Sweden. In 2010 the top importers of SALW (those with annual imports of at least USD 100 million), according to available customs data, were (in descending order) the United States, the United Kingdom, Canada, Germany, Australia, South Korea, France, and Thailand (Small Arms Survey 2013). ${ }^{2}$ When it comes to international trafficking of major weapons, the flow of arms to Africa, the Americas, and Asia and Oceania increased significantly between 2004 2013. European imports however decreased by 25 per cent between 2004-2013. The UK was the largest importer of major weapons in Europe, followed by Azerbaijan and Greece. Many European states are choosing second-hand weapons as cheaper alternatives. The level of arms transfers to the Middle East remained more or less unchanged (Wezemen \& Wezemen 2014). ${ }^{3}$

SALW trafficking involves a host of actors ranging from the individual rogue seller and buyer to intermediaries, transnational networks, transport companies, states, and corporate organizations (Rothe and Collins 2011). Some trafficking operations appear to be more sophisticated and to involve organized crime groups, licensed dealers, and/or corrupt state officials, while others are a result of theft, for example. In the literature (see, Rothe and Collins 2011; Cragin and Hoffman 2003), four types of markets for small arms sales are mentioned; white, black, gray, and covert military transactions. The white market refers to the legal sale of weapons by governments or private manufacturers to other countries or governments. While the white market is considered a legal market, a large proportion of trafficked arms are said to originate from government weapons surplus that make their way into the illicit market (Greene 2000).

Black market deals are illegal by the covert nature of the transaction as well as through the illegal status of the buyer, seller, or transaction. Transactions can be hidden through the concealment of the weapons through mislabeling, forging of documents, and the laundering of the criminal proceeds. This also includes covert government (military) transfers of arms to another country, specifically to insurgent forces due to their lack of transparency (Mouzos 2002; Rothe and Collins 2011).

The gray market makes reference to those transactions that are not considered illegal, but do not fall within the category of white market dealings. For example, while there are direct

\footnotetext{
${ }^{1}$ Generally, small arms are weapons operable by an individual, including revolvers and self-loading pistols, rifles and carbines, assault rifles, submachine guns, and light machine guns. Light weapons are operable by two or more people, and include heavy machine guns, hand-held under-barrel and mounted grenade launchers, portable anti-tank and anti-aircraft guns, and so on.

${ }^{2}$ According to SIPRI Stockholm International Peace Research Institute (SIPRI), the five biggest exporters of major weapons in 2009-13 were the United States, Russia, Germany, China and France and the five biggest importers were India, China, Pakistan, the United Arab Emirates (UAE) and Saudi Arabia (Wezemen \& Wezemen 2014).

${ }^{3}$ The Stockholm International Peace Research Institute, a leading global think tank researching conflict and arms, also reports on the world's Top 100 arms-producing companies, with the exception of China, Kazakhstan, and Ukraine due to lack of available data.
} 
violations of arms embargoes (black market deals), there are also sales of arms to a nonembargo country (B) with the knowledge that such arms will then be sold to the intended state (A) to bypass the embargo, through the use of proxy individual brokers or insurgency groups (see, Rothe and Collins 2011).

In the US most firearms appear to be trafficked via a corrupt licensed dealer (see Fig. 1). A similar situation is reported in Australia (Bricknell 2012). Licensed firearm dealers are well placed to divert firearms - they have access to large firearm collections, and their familiarity with legislation and processes around the importation, sale and distribution of firearms will have revealed where vulnerabilities exist and can be best exploited. Theft is also cited as an important source of illegal firearms in countries such as the US (Kleck and Wang 2009; Wright and Rossi 1994) and inferred in other jurisdictions such as England and Wales (Hales et al. 2006) and within the European Union (Spapens 2007).

The trafficking of firearms is unlike many of the other forms of trafficking. Unlike drugs, cigarettes, or counterfeit pharmaceuticals, AK-47 will last indefinitely. As a result, a logical argument follows: arms trafficking is episodic, often from an established stockpile to a region descending into crisis (UNODC 2010). However, the "rationality" of the illicit firearms market is one of the topics further discussed in this special issue, since this market deals with a product that is significantly different from other illicit products or services offered by criminal networks. For example, it is essential to understand that the inherent nature of firearms and other weapons is their ability to take and/or protect human life. Their ability is to intimidate, threaten or defend the survival of "imagined communities" including, groups, gangs, and nation states. Arms do not only help rebel groups and governments to maintain control over territories, but they are also a very "useful tool" for expanding the influence of organized crime groups and for projecting "masculinity" (Davis et al. 2001; Arsovska and Kostakos 2008).

\section{Demand for Firearms: Conflict, Crime, and Culture}

Research indicates that there are two primary markets for illicit arms - those who need weapons for political purposes, and those who need them for criminal ones. Frequently, the illegal weapons trade flourishes in neighborhoods that are terrorized by organized crime

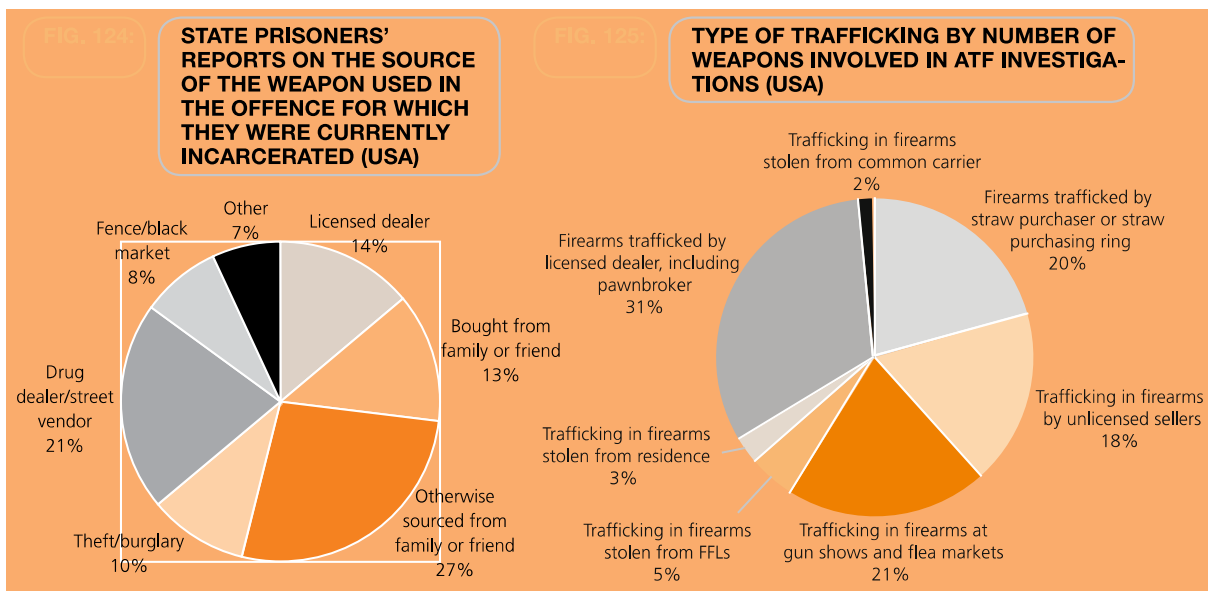

Fig. 1 Source of weapons and type of trafficking Source: UNODC Transnational Organized Crime Threat Assessment (2012) (Based on US Bureau of Justice Statistics 2002 \& ATF 2000) 
groups and violent offenders, as well as in war zones where rebels attack civilians. The majority of firearms (roughly two-thirds) end up in the hands of violent non-state actors and civilians. States, however, also play an important role in the arms trade, particularly when they are subjects to international embargoes and attempt to circumvent these controls. Finally, "gun culture" may also provide an explanation as to why in some parts of the world there is a steady demand for weapons despite the fact that there are no apparent crises or ongoing conflicts. The contributions in this special issue discuss these topics.

\section{States and UN Embargos}

One rational choice-inspired argument is that laws, criminalization of specific behaviors/acts, and punishments may deter people, including arms traffickers to commit crime. However, when it comes to imposing arms embargoes on states, regulations and punishments seem to lead to various unintended consequences, not necessarily decrease in arms trafficking. Some of the articles in this issue elaborate on the role of states and RCT-inspired anti-arms trafficking policies in controlling and/or facilitating the illicit firearms market.

For example, when the wars in Yugoslavia started, one of the international community's first reactions was the UN arms embargo, imposed on all Yugoslav republics: Bosnia-Herzegovina, Croatia, Macedonia, Montenegro, Serbia (including Kosovo and Vojvodina), and Slovenia in 1992. Although, initially this seemed to have little effect on Serbia, which maintained the control of the Yugoslav Army, the embargo badly hit the defense forces of Bosnia, Croatia, and Kosovo. Research shows that in order to push forward for their independence, the former Yugoslav republics had to engage in alliances with foreign state and nonstate actors for the importation of weapons (see Arsovska \& Zabyelina in this issue). Between 1994 and 1996, Iran was one of the main weapons suppliers of the Bosnian government. Arms were also coming into the Balkan region from Chile and other parts of South America, in violation of the UN arms embargo. One Chilean shipment was disguised as humanitarian aid to Sri Lanka (see Arsovska \& Zabyelina in this issue).

The Russian Federation and other Soviet successor states are widely known to have been actively involved in the arms trade. Similarly to the Balkan countries, when the Soviet Union collapsed many former bureaucrats from the military and secret security services used their connections and "know-how" and got involved in the arms trade (see Saunders \& Thauchuk in this issue). In one incident from 2007, Venezuela purchased 100,000 AK-103 $39 \mathrm{~mm}$ assault rifles from Russia to replace weapons purchased in the 1950s from Belgium. The US Department of State and the government of Colombia feared that these weapons, which are also the favorite of the strongest Colombian guerrilla group, FARC, might be diverted to Colombia illegally and sold to FARC (see Jonsson \& Brennan in this issue).

In Asia, following the independence of Myanmar from the British Empire in 1948, the bond between the Communist Party of Burma (CPB) in Myanmar and the People's Republic of China grew stronger over time. However, after the CPB collapsed in 1989, its demise led to the emergence of the United Wa State Army (UWSA). Over the years Wa kept very close relations with China, and cross-border trade, including firearms trade, increased along the SinoMyanmar border. With the help of China, UWSA did not only obtain SALW but also military grade weaponry (MANPADS) (see Jonsson \& Brennan in this issue). As argued in this special issue, the transfer of MANPADS from state actors to non-state actors has been identified in several countries around the world including, Myanmar, Afghanistan, Somalia, and Iraq.

In Africa, the illegal small arms trade has been of major concern for decades as well (see Florquin, and Strazzari \& Simone in this issue). In Somalia, Ethiopian truck convoys deliver illegally obtained weapons, violating the UN embargo. Liberia under the rule of Charles Taylor 
transported weapons across the border into Sierra Leone, supplying the Revolutionary United Front, a rebel group that fought and lost an 11-year civil war. In 2002, a group of West African gun smugglers persuaded the Nicaraguan government to sell it 3000 assault rifles and 2.5 million rounds of ammunition by pretending to be brokering the deal on behalf of the Panamanian National Police. Instead, the illegal goods were routed to South America and sold to the United Self-Defense Forces of Columbia, an international terrorist organization.

Government corruption is seemingly intrinsic in global arms deals (see Feinstein 2011). Governments often use private arms brokers to traffic weapons, and the use of bribery is not uncommon. Concepts such as "survival of ethnic communities," "independence" and "nation building" have kept this market high-profit-low-risk. Thus many states have been actively involved in the illicit arms trade, often in violation of UN arms embargos. Some of the articles in this issue explore the links between states, international laws, corrupt officials, lack of political will, and the illicit firearms market.

\section{Violent Non-State Actors: Insurgents and Organized Crime Groups}

It has been argued that during the past two decades there has been a drastic decline in state support of insurgent groups (Giraldo and Trinkunas 2007). This has prompted insurgent groups to develop new sources of income, including diaspora support, domestic crime such as robberies, extortion and kidnappings as well as transnational, organized criminality (see Jonsson \& Brennan; and Arsovska \& Zabyelina in this issue). Hence, taxation of or direct involvement in drug trafficking has proven to be a great source of income, as well as weapons, for insurgent groups. For example, FARC and UWSA represent two of the oldest armed groups in the world that have benefited from drug trafficking, extortion, and other crimes in order to arm themselves (see Jonsson \& Brennan in this issue).

Also the rebellion that swept Libya in the spring of 2011 started out as a popular protest, and then slowly transformed into a bloody armed conflict. However, only certain groups close to the authorities were permitted to own weapons. Thus, when protests started, rebels had to find ways to acquire weapons via illegal means (see Strazzari \& Simone in this issue). This scenario resembles that of the ethnic Albanian Kosovo Liberation Army (KLA) during the Kosovo conflict. The KLA, in order to arm itself, established contacts with the ethnic Albanian diaspora as well as with Albanian organized crime figures operating throughout the West for the supply of weapons (see Arsovska \& Zabyelina in this issue). Following the March 1997 looting in Albania, tens of thousands of hand-guns, Kalashnikovs, machine-guns and anti-tank rocket launchers, ended up in the hands of the KLA (labeled as a terrorist organization by the US until 1998) through the black and gray markets (see Arsovska \& Zabyelina in this issue)

Moreover, Pakistan is the home to Darra Adam Khel (The Arms Market), the largest illegal arms market in the world. The weapons are some of the cheapest in the world; an AK-47 costs $\$ 50$ USD, whereas Iranian and Russian weapons cost \$300 USD and up. The guns are replicas of those supplied by the US to the Mujahadeen during the 1980s when the USSR invaded Afghanistan (Khan 2006). After the war, the Pashtuns helped supply the Taliban when they began to overrun Afghanistan, and also covertly supplied the Irish Republican Army, the Middle East, and the Muslims in Kashmir. According to BBC, influential traders in Darra Adam Khel proudly talk about their role in arming the Islamist fighters engaged in Kashmir (Khan 2006).

Violent non-state actors such as the Real IRA and the Basque ETA organization are believed to be sourcing weaponry from the Balkans and other parts of the world. The UK government has recently secured the extradition of, and charged, three men arrested in Slovakia on suspicion of gunrunning for the Real IRA, which is believed to have developed links with allies of Radovan Karadzic, the Bosnian Serb leader charged with war crimes. Also, 
the rocket used in the attack on the British MI6 London headquarters in September 2000 was an RPG22, manufactured in either Bulgaria or Russia and obtained in the former Yugoslavia. NCIS UK also notes that firearms are often entering the UK alongside drug consignments which confirms the strong link between firearms possession and drug trafficking (Davis et al. 2001).

Similarly, in Spain a substantial shift in ETA's sources of supply is noted. From previous purchasing on the Belgian black market, the group has begun to acquire materiel in the former Yugoslavia, "using similar methods and channels to those employed by Italian Mafia groups and Colombian drug traffickers." Indeed, the president of the Aragon People's Party was assassinated by a member of ETA with a Croatian revolver, bought on the black market and smuggled into Spain. Further evidence for such supply routes can be seen in Amsterdam, where in recent years large quantities of Eastern-European-produced weapons have been found. The Dutch authorities believe the arms were destined for terrorist groups, since they were not the kind used in bank robberies (Davis et al. 2001).

As noted earlier, not only rebels and terrorist groups but also organized crime groups tend to make use of illicit firearms. It is estimated that the Camorra group, historically rooted in Naples, is responsible for almost half (48 percent) of all mafia homicides documented in Italy over the period 1992-2010. A greater availability of firearms in the region and a stronger presence of organized crime members may partly explain the group's predominance in violence. However, it appears that in more recent years mafia homicides have started to decline (Small Arms Survey 2013). Analysts suggest that organized crime groups have entered a submersion phase, moving further into legal markets. Most mafia clans nevertheless maintain their own arsenals of collectively held firearms. The level of sophistication of firearms among mafia clans have increased since the 1970s. Most mafia members rely on machine guns, revolvers, pistols, and AK-pattern assault rifles. Criminal groups in the former Yugoslavia, Albania, and other Eastern European countries are known to be key sources of firearms for Italian organized crime groups (Small Arms Survey 2013).

Therefore for decades, SALW have fed the local criminal underworld thus contributing to the undermining of West European as well as global public safety. SALW are both a means of protecting the illegal activities of organized crime groups and a base of activity and source of income for groups engaged in the trafficking of illegal commodities. The former Greek Minister of Public Order, Mikhail Khrisokhoidhis, stressed the strong linkages between arms trafficking and criminal gangs, who also run drug and human trafficking routes: "If you wish to fight organised crime in Greece, first of all you have to deal a hard blow to illegal arms trafficking" (Davis et al. 2001).

Some of the articles in this special issue examine the symbiotic relationship between arms procurement and drug trafficking as well as the relationship between insurgent groups, transnational organized crime, and state sponsors. Many are policy oriented and explain how by monitoring closely price changes of arms and by developing better tracking system of firearms, governments may come up with a more effective method for reducing and/or controlling the black and gray firearms market. Governments, with the help of NGOs and scholars, need to examine carefully the arms prices and arms availability of weapons to certain groups in order to better understand the nature, duration, and outcome of emerging and ongoing conflicts.

\section{Civilians, Street Crime, and Gun Cultures}

Although significant amounts of SALW end up in the hands of warlords, insurgents and organized crime groups, civilian ownership of firearms has been the fastest-growing category; as consumers buy more guns and as former military weapons gradually shift into civilian 
hands (Stohl 1999; Small Arms Survey 2012). Some of the articles in this special issue focus on civilian gun ownership and the demand for weapons.

No doubt that illegal weapons trade exists in area with strong "gun cultures." Gun cultures are found around the world, particularly in places such as the US, Honduras, El Salvador, Australia, Canada, the Philippines, Germany, and Switzerland. Gun culture, or so-called "pistolization," indicates the taken-for-granted cultural practice of carrying a handgun as an accouterment of everyday life (Cook et al. 2009). It is a socially constructed cultural practice that has links to conceptions of masculine power and, in some instances, has been constructed as a symbol of manly prosperity. Among the most studied and discussed global gun cultures is that of the United States. Americans have 270 million privately held firearms and they also have the highest gun ownership per capita rate in the world, with an average of about nine guns for every 10 Americans (Cook et al. 2009).

The second highest gun ownership rate in the world is Yemen (Small Arms Survey 2012; Fisher 2012). Israel has only 7.3 privately owned guns for every 100 people, which means that the American rate is 12 times as large. Israel's gun ownership rate however is about 12 times that of Japan (Small Arms Survey 2012; Fisher 2012). This special issue examines understudied cases of "gun cultures" such as the Balkan region and North Caucuses. It looks at the role of emotions such as fear and insecurity, and traditional and pop culture in shaping public opinions about guns and affecting the illicit firearms market (see Arsovska \& Zabyelina in this issue).

The NCIS UK Threat Assessment on Serious and Organised Crime 2000 however notes that despite the fact that at present the UK does not have a particularly strong gun culture, this trend seem to be changing due to presence of organized crime groups and an increase in the use of firearms among organized criminals. The presence of crime leads to feelings of insecurity, which leads to an increased demand for weapons. Thus the presence of criminal groups creates a market for illicit firearms, which in turn leads to the creation of gun cultures. Gun crimes in London rose by 11 percent in 2000, reaching the highest figure for seven years. In August 2001 a prosecuting judge noted "rising police anxiety" about the levels of gun crime in London. Shots are now fired in London on a daily basis, "incidents involving handguns are running into double figures every week", and the number of gunshot casualties is said to have now reached proportions which the health services are not equipped to deal with. Faced with the "frightening increase" in illegal guns, the UK police "have been looking at countries like the US and Canada where firearms are more prevalent... to see what lessons we can learn" (Davis et al. 2001; see also Morselli \& Blais in this issue).

France has seen the same worrying trends, with weapons entering France in ever rising numbers particularly from the Balkans. "Pistols, assault rifles and even rocket launchers... turn up in France ever more frequently since the collapse of the Soviet Union and the Balkans conflicts." Similarly, the Greek police estimate that approximately 350,000 to 400,000 illegal weapons have been imported into the country around 2000, providing such a ready availability of relatively cheap arms that criminals but also common people buy and sometimes use (Davis et al. 2001).

In Portugal police sources say that "modified guns are as easily accessible as any common good." Today it is common to find people, either for criminal reasons or purely for self-defense (or due to media influence), with modified guns of a 6.35 calibre. This increase in the supply and availability of arms to criminal groups and civilians risks the emergence of a "culture of violence." Armed crime could easily lead to the privatization of security and the increased spread and use of arms as communities seek to defend themselves.

Some of the articles argue that by taking a more inclusive approach to understanding the nature of the illicit firearms market and by focusing on the demand side, we can develop more 
effective policies. Arms-reduction programs should equally take into consideration culturallyenriched and socially-embedded factors that may have an impact on the illicit market in firearms. Other articles in this issue, however, provide hands-on policies for law enforcement officials and note that criminals too can create demand for weapons so better monitoring of guns is essential. For example, the registration status of a gun provides an information base that may enable law enforcement officials to keep pace with the wide variety of firearms that enter the illegal market at some point during their lifecycle. Thus, harmonizing measures and variables across different data sets, centralizing data sets within countries, and decentralizing intervention strategies across countries, are some of the practical recommendations discussed in this issue (see Morselli \& Blais in this issue)

\section{Contributions}

This special issue contains six articles that study the global illicit firearms market. The articles focus on the black and gray markets for illicit firearms, particularly SALW but also MANPADS. They contribute toward our understanding of the illicit firearms market in various regions around the world, including: the roles that states, violent non-state actors, corporations, and civilians play in this market; the criminal, political and cultural demand for weapons; the rational and normative-affective considerations of those demanding and those selling weapons; and the effectiveness of various measures and policies trying to regulate the illicit firearms market.

Some articles focus on the "character" of armed conflicts by studying arms prices and access to weapons before and after conflict, and links between rebel groups, state officials and organized crime groups. These articles look at the politics of the illicit firearms market and aim at explaining conflict dynamics by examining why and how rebel groups obtain guns. They also examine how arms availability and arms prices have conditioned the political landscape of some countries.

Other articles take a more criminological approach. They focus on the criminal and cultural demand rather than the political demand for weapons. They examine the operational methods and decision making of arms traffickers, their ability to adjust to external environments as well as the degree to which normative-affective considerations play a role in the decision to obtain an illicit firearm. Overall, the articles in this special issue also offer unique methodological insights into these highly understudied topics.

In their paper, Michael Jonsson, a Ph.D. researcher at the Department of Government at Uppsala University in Sweden, and Elliot Brennan, a non-resident research fellow at the Institute for Security and Development Policy, also in Sweden, explain how insurgent groups have financed their arms procurement through drug trafficking, and what are some possible reasons for the long duration of conflicts in drug producing countries. Although during the past decade a common argument has been that extensive financing of rebel groups results in longduration, high-intensity civil wars, the authors argue that the most influential lines of research build on the argument that all rebel groups are not created alike. Jonsson and Brennan find that the military capacity of armed groups is dependent not on funding alone, but also on access to military grade weaponry, which can predominantly be provided by state sponsors of rebellion. The authors argue that incomes generated from the drug trade do not automatically translate into improved military capabilities, since access to military-grade weapons requires stable state support. Their paper compares the arms procurement of the Fuerzas Armadas Revolucionarias de Colombia (FARC) and the United Wa State Army (UWSA) in Myanmar, and elaborates on the nexus between rebel groups, organized crime, and states. 
Francesco Strazzari a senior research fellow at the Norwegian Institute of Foreign Affairs in Oslo, Norway, and Simone Tholens, a post-doctoral researcher at the Robert Schuman Centre for Advanced Studies at the European University Institute in Italy, elaborate on the arms and conflict dynamics in Libya and the Sahara-Sahel Region. They examine the link between arms availability and the trajectory of contemporary armed conflicts. More specifically, their article focuses on the effects of arms dynamics on the evolution and character of the war in Libya in 2011. Strazzari and Tholens study the implication that increased arms availability has on the organization of armed groups involved in wars against states. The authors show the ways in which weapons from Libya have rekindled or altered local conflicts, creating permissive conditions for new tactical options, and accelerating splintering processes within armed movements in the Sahara-Sahel region.

Nicolas Florquin, a senior researcher at Small Arms Survey in Geneva, Switzerland looks at the factors that drive the prices of arms and ammunition sold at illicit markets. He examines whether prices of illegal arms soar during episodes of marked insecurity. The article seeks to advance knowledge on the dynamics and determinants of weapons prices through quantitative analysis of illicit arms market price data in Lebanon for the period February 2011 to September 2012. The article also examines the relationship between arms and ammunition prices in Lebanon, and reported conflict fatalities in Syria. The author found statistically significant correlations between firearms "demand" and firearm prices as well as between the prices of arms and ammunition and reported conflict fatalities. The author argues that it is essential to monitor the illicit arms market prices, including prices for a diverse range of weapons and ammunition, to improve our understanding of both illicit markets and conflict dynamics.

Moreover, Kimberley Thachuk, a senior intelligence analyst at Principle Global Perspective Group and a part time lecturer at Elliott School of International Affairs at George Washington University, and Karen Saunders, fellow at the Forum Foundation for Analytical Excellence in Virginia, examined the business of airborne illicit arms trafficking, and the complex nexus between transport companies, organized criminals, corrupt officials in the source and destination countries and international transport laws and standards. The authors argue that airborne illicit arms trafficking resembles very much licit businesses in terms of access to products requested by costumers, links to reliable supply chains to meet the demand for specific products, overall operational methods and strategies, and ability to adjust over time. The authors explain that groups are able to maneuver quickly in difficult operational environment. The case study the authors selected is the airborne illicit arms trade networks from the former Soviet space. Thachuk and Saunders argue that understanding these networks as rational commercial entities that are calculative, money driven and aim at improving their market performance and ensuring their continuity, would help law enforcement officials in developing appropriate strategies to combat these groups. Such approach, the authors argue, can lead to the development of methods of intervention and interdiction.

Carlo Morselli, Professor at the School of Criminology (Centre international de criminology compare) at University of Montréal, and Dominik Blais, from the same university in in Montréal, Canada, also study the illicit firearms market from a crime perspective, focusing more on the use of illicit firearms in a criminal and not a political context. The authors examine how long it takes for a gun to get involved in a crime, and once a gun has entered the illegal market, how long it takes before authorities recover it, and how far crime guns travel. This study focuses on guns that entered the illegal firearm market through thefts. The findings show that non-registered crime guns take longer to find and travel lengthier distances between the moments and points of theft and seizure. Consequently, the authors identified ways to improve detection, follow-up, and intervention in this area. The findings call for a greater effort from more localized teams of law-enforcement agents and analysts that may keep track of guns 
within their specific jurisdictions and likely reduce the length of time that a firearm remains in illegal circulation. Morselli and Blais use a mix of national (Canada) and provincial (Quebec) data on crime guns.

Finally, Jana Arsovska, Assistant Professor at John Jay College of Criminal Justice in New York, and Yuliya Zabyelina, Newton International Fellow at Edinburgh University, study arms trafficking from sociological and criminological perspective, and aim at understanding the illicit firearms market dynamic beyond the rational choice and crime perspectives. They argue that despite strict regulations on the import, export, ownership, use, transfer, and storage of licit firearms, there exists, in many countries around the world, a potentially large pool of illicit firearms and an ongoing demand for such weapons. This article discusses the illicit firearms markets in the Balkans and the North Caucasus. By studying the demand side of the market, it provides some possible explanations as to why arms reduction measures often fail or have limited results. It argues that cultural attitudes, socio-political complexity, and emotions could explain much of the "irrational" behavior of those demanding weapons. Arsovska and Zabyelina try to construct a multifaceted conceptualization of human choice that focuses not only on the functionality of firearms but also on their symbolic meaning.

In conclusion, in 2006, more than 100 member nations of the UN General Assembly (UNGA) submitted their views on creating a possible Arms Trade Treaty (ATT). On April 2, 2013, the UNGA finally adopted an ATT. The argument has been that the treaty makes it harder for human rights abusers, criminals, and arms traffickers to obtain weapons. However, laws, treaties, and conventions are only one, albeit important, part of the puzzle. Policy makers must understand the nature of the firearms market first; as argued earlier, firearms are products different than any other illicit product or service, and need to be analyzed as such.

In addition to improving the methods of tracking, monitoring and detecting of illicit firearms domestically and globally, scholars and practitioners should also pay closer attention to the demand side of this illicit market. The role of media and emerging gun cultures as well as emotions and insecurity need to be addressed and studied properly in relation to illicit firearms in order for policy makers to develop more effective arms-reduction policies. The articles in this issue explain how and why culture, economic conditions, power, and sociopolitical environment have a significant impact on people's preferences and wants, and thus have important effects on the rise/decline in illicit firearms. Last but not least, the articles acknowledge that if there is no sincere political will to deal with the issue of arms trafficking, the global illicit firearms market will continue to flourish since states often play a vital role in the arms trafficking chain.

\section{References}

Arsovska, J., \& Kostakos, P. (2008). Illicit arms trafficking and the limits of rational choice theory: the case of the Balkans. Trends in Organized Crime, 11(4), 352-387.

Bassiouni, M. C. (2010). Introduction: "Crimes of State" and other forms of collective group violence by nonstate actors. In D. L. Rothe \& C. Mullins (Eds.), State crime, current perspectives (pp. 1-21). New Brunswick: Rutgers University Press.

Bricknell, S. (2012). Firearm trafficking and serious and organised crime gangs. Australian Institute of Criminology (AIC). Research and public Policy Series 116. Canberra: Australian Institute of Criminology.

Cook, J. P., Cukier, W., \& Krause, K. (2009). The illicit firearms trade in North America. Criminology \& Criminal Justice, 9(3), 265-286.

Cragin, K., \& Hoffman, B. (2003). Arms trafficking in Colombia. Santa Monica: RAND National Defense Research Institute. 
Davis, I., Hirst, C., \& Mariani, B. (2001). Organised crime, corruption and illicit arms trafficking in an enlarged EU: Challenges and perspectives. London: Saferworld Arms \& Security Programme.

Feinstein, A. (2011). The shadow world: Inside the global arms trade. New York: Picador.

Fisher, M. (2012). "What makes America's gun culture totally unique in the world, in four charts" Washington Post. December 15 [www.washingtonpost.com/blogs/worldviews/wp/2012/12/15/what-makes-americasgun-culture-totally-unique-in-the-world-as-demonstrated-in-four-charts/].

Giraldo, J. K., \& Trinkunas, H. A. (2007). The political economy of terrorism financing. In J. K. Giraldo \& H. A. Trinkunas (Eds.), Terrorism financing and state responses: A comparative perspective (pp. 7-20). Stanford: Stanford University Press.

Greene, O. (2000). Examining international responses to illicit arms trafficking. Crime, Law and Social Change, $33,151-190$.

Hales, G., Lewis, C., \& Silverstone, D. (2006). Gun crime: The market in and use of illegal firearms. Home Office Research Study 298. London: Home Office.

Khan, A. A. (2006). "Pakistan's flourishing arms bazaar" BBC News. June 21. http://news.bbc.co.uk/2/hi/south asia/5066860.stm.

Kleck, G., \& Wang, S. Y. K. (2009). The myth of big-time gun trafficking and the over-interpretation of gun tracing data. UCLA Law Review, 56, 1233-1294.

Mouzos, J. (2002). Firearms theft in Australia. Trends \& Issues in Crime and Criminal Justice no. 230. Canberra: Australian Institute of Criminology.

Rothe, L. D., \& Collins, V. (2011). An exploration of applying system criminality to arms trafficking. International Criminal Justice Review, 21(1), 22-38.

Shah, A. (2006). "Small Arms - they cause $90 \%$ of civilian casualties." Global Issues. 21 Jan. 2006. [www. globalissues.org/article/78/small-arms-they-cause-90-of-civilian-casualties].

Small Arms Survey. (2012). Moving targets. Cambridge: Cambridge University Press.

Small Arms Survey (2013). Overview: Illicit Trafficking. [www.smallarmssurvey.org/weapons-and-markets/ transfers/illicit-trafficking.html].

Spapens, T. (2007). Trafficking in illicit firearms for criminal purposes within the European Union. European Journal of Crime, Criminal Law and Criminal Justice, 15(3-4), 359-381.

Stohl, M. (1999). Small arms and failed states. America's Defense Monitor Program. [www.cdi.org/ada/1307/ transcript.html].

The Office for Disarmament Affairs. The United Nations (2013). [http://www.un.org/disarmament/convarms/ SALW/.

United Nations General Assembly (UNGA) (2001). Protocol against the illicit manufacturing of and trafficking in firearms, their parts and components and ammunition, supplementing the United Nations Convention against Transnational Organized Crime.

UNODC (2010). The Globalization of Crime. Transnational Organized Crime Threat Assessment. Vienna: UNODC. [www.unodc.org/documents/data-and-analysis/tocta/TOCTA_Report_2010_low_res.pdf].

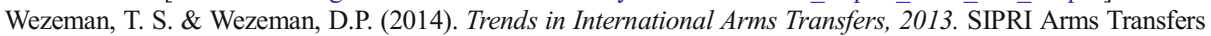
Programme.

Wright, J., \& Rossi, P. H. (1994). Armed and considered dangerous: A survey of felons and their firearms (2nd edn.). New York: Aldine de Gruyter. 